\title{
The Cultural Heritage of Bubak Kawah in Wedding Ceremony of Surakarta
}

\author{
P A Krahmadie ${ }^{1}$, N E Wardhani², A Rakhmawati ${ }^{2}$ \\ ${ }^{1,2,3}$ Universitas Sebelas Maret, Surakarta, Indonesia \\ E-mail : puteriearnie.krahmadie13@gmail.com
}

\begin{abstract}
This study discusses the ritual tradition of Bubak Kawah in Surakarta traditional wedding ceremony. The focus of this research is the cultural meaning contained in Bubak Kawah ritual. The purpose of this research is to look for noble values and cultural meanings in one of the ritual sequences in Surakarta's traditional wedding ceremony. This study employed qualitative research methods. The results of this study explain the meanings and values contained in the Bubak Kawah ritual. The meaning and values in this ritual can be shown through symbols and equipment used in the ritual. Broadly speaking, Bubak Kawah ritual describes the filial form of the bride and groom to the parents. The bride and groom are expected to be able to always remember parents who have given birth, raised and educated them. Through cultural meanings, it is hoped that the community can understand, maintain and preserve the existing customs and culture of Bubak Kawah.
\end{abstract}

Keywords: Bubak Kawah; Surakarta Traditional Wedding Ceremony; Cultural Meanings

\section{INTRODUCTION}

Surakarta City is known as one of the cities that is rich in arts and culture. Surakarta, often called the city of Solo, is a cultural center on Java, especially Central Java. The existence of Surakarta Kasunanan Palace makes Surakarta the center of culture. Javanese culture that lives in the cities of Yogyakarta and Solo is a civilization rooted in the Palace. Surakarta Palace is one of the places that holds all the original heritage of the ancestors. One inheritance that is still kept neatly is customs and culture.

One of the traditional heritage that is still used and preserved by the people of Surakarta is the custom of wedding ceremony. The people of Surakarta up to now still use customs originating from the palace of Surakarta, especially about wedding ceremony. Surakarta's customary wedding ceremony is still thick with rituals that are carried out from before the 
wedding ceremony to the core ceremony. The equipment used in Surakarta's traditional wedding rituals is detailed.

Adat or customs can be interpreted, including: (1) rules that are commonly obeyed or carried out since time immemorial; (2) ways that have become habitual; (3) the form of cultural ideas consisting of cultural values, norms, laws, and rules with one another relating to a system (in http://kamusbahasaindonesia.org.).

Customs are complex norms by adherents considered important in living in the society. These customs are useful as guidelines for their behavior, and guidelines for controlling every human act or behavior. Therefore, the understanding of customs and society itself is a place of culture. Culture as knowledge acquired by humans is used to interpret experiences and results behavior [1].

In traditional Javanese wedding ceremony, there are various series of things to do. The series of ceremonies included bubak kawah. This ritual is a series that complements the Javanese traditional wedding ceremony. This research is an attempt to explain the cultural meaning and values contained in the bubak kawah ceremony. Cultural meanings and values in this ritual can basically be expressed through the symbols and equipment used during the ceremony [2].

The researcher took the ritual of bubak kawah because it was interesting to be used as the object of research, as there were already many Javanese people, especially the younger generation who did not know the meaning and value contained in the ritual. In bubak kawah ritual, there are also educational values and cultural meanings that must be understood and preserved, so that the cultural heritage remains and is not left behind by the younger generation.

\section{METHOD}

This study is qualitative research methods. Qualitative research according to Lexy J. Moleong is research that intends to understand the phenomenon of what is experienced by the subject of research such as behavior, perception, motivation, action, etc. in a holistic manner and by means of descriptions in the form of words- words and languages, in a special natural context and by utilizing various scientific methods [3]. So, the results of this study are in the form of a description or explanation of the object of research. Research with a qualitative approach emphasizes the analysis of the process of deductive inference as well as on the analysis of the dynamics of relations between observed phenomena, using scientific logic [4]. Qualitative research is research that emphasizes the analysis process.

In this qualitative research, there is one theory that supports and has an important position, namely cultural theory. Culture is knowledge acquired by someone and is used to interpret experiences that produce behavior [5]. Diverse culture found in a society will form different characters and thoughts.

\section{RESULT AND DISCUSSION}

Marriage is an inner bond between men and women to form a family. Marriage is one of the bridges to enter real household life. In Java, especially in Surakarta, marriage is a ceremony that is considered sacred and contains various meanings and values. Ceremony is a series of actions or actions that are bound by customary rules [6]. Zulfajri also stated that the ceremony was a celebration carried out in connection with an important event. 
Surakarta traditional wedding ceremony has a variety of rituals that must be done, starting from before, during and after the wedding ceremony. The sequence of Surakarta traditional wedding ceremony starts from before the ijab qabul is carried out: lamaran (panembung), paningset, liru kalpika, sowan leluhur, wilujengan, pasang tarub, tuwuhan, siraman, paes, sadeyan dhawet, sengekran, midodareni, nikah/ijab, panggih, sepasaran/wilujengan [7]. There are various rituals in this series of Surakarta traditional wedding ceremonies, caused by efforts to preserve the customs and culture of ancestral heritage. All rituals and customs found in the Javanese wedding ceremony are sourced from the Surakarta Palace.

\subsection{The definition of Bubak Kawah ritual}

In the sequence of the Surakarta traditional wedding ceremony, there is one ritual called bubak kawah. This ritual is carried out after the ceremony of calling the bride and groom. This ritual is not carried out by every community that carries out the wedding ceremony, because as time goes by, the society prioritizes time efficiency. Lack of awareness and lack of knowledge about bubak kawah make this ritual often left behind in a series of traditional Surakarta wedding ceremonies.

Bubak Kawah is a ceremony asking for blessing of offspring by drinking rujak degan, done in before krobongan ceremony and after the ceremony to call the bride to the first manton. There are a number of traditional ways to beg for descendants for newlyweds, for example by tuwuhan pairs in front of the Cantonese house, drinking rujak on the bubak kawah ceremony, and so on. Bubak Kawah Ceremony (bubak: opening the land, kawah: water that comes out from the mother before the baby is born) which is marked by drinking young coconut salad (degan, dawegan), specifically done by the bride jaka lara (girl virgin) and at the first manton (not necessarily manton firstborn) [8].

The purpose of bubak kawah is to ask the Almighty God about (1) that the new family (newlyweds) be given spiritual physical freshness so that they are able to carry out the duties of living in the family (family), (2) so that the new family is trusted by God, soon blessed the son as a descendant, (3) illustrates how big the parents' responsibility for his son is, and how hard it is to organize the first manton, as well as opening new land, but for the sake of child survival and continuity of descent undoubtedly the feeling of being light and fresh, like fresh rujak degan.

The order of the ceremony is not always the same between the regions. Each region has its own way, there are those who follow the way of the palace there are also those who apply habits outside the palace. In general, people in Surakarta use custom according to their respective regions. The bubak kawah ceremony is carried out in front of the krobongan (patanen), shortly after the ceremony to call the bride to the first manton. The actors are father, mother, newlyweds and ancestors who manage the course of the event. The equipment is in the form of two kinds of salad, namely sweet salad and savory salad. Rujak legi is a fresh drink made from various sweet fruits and given sugar water. Savory rujak is a fresh drink made from young coconut water mixed with young coconut meat itself. In its development the ceremony of bubak kawah only uses one type of drink, rujak degan.

In its development, the sequence of rituals of bubak kawah is accompanied by a procession of pikulan. The process of picking up is carried out at the very end of the ritual. In general, pikulan carry household items such as: 1) ian, 2) fans, 3) siwur, 4) centhong, 5) irus, 6) munthu, 
7) pari, 8) kendhil, 9) kukusan, 10) and so on. These items have meaning as advice for both the bride and the groom as husband and wife, the pikulan items will be contested later [9].

Figure 1. Pikulan Process

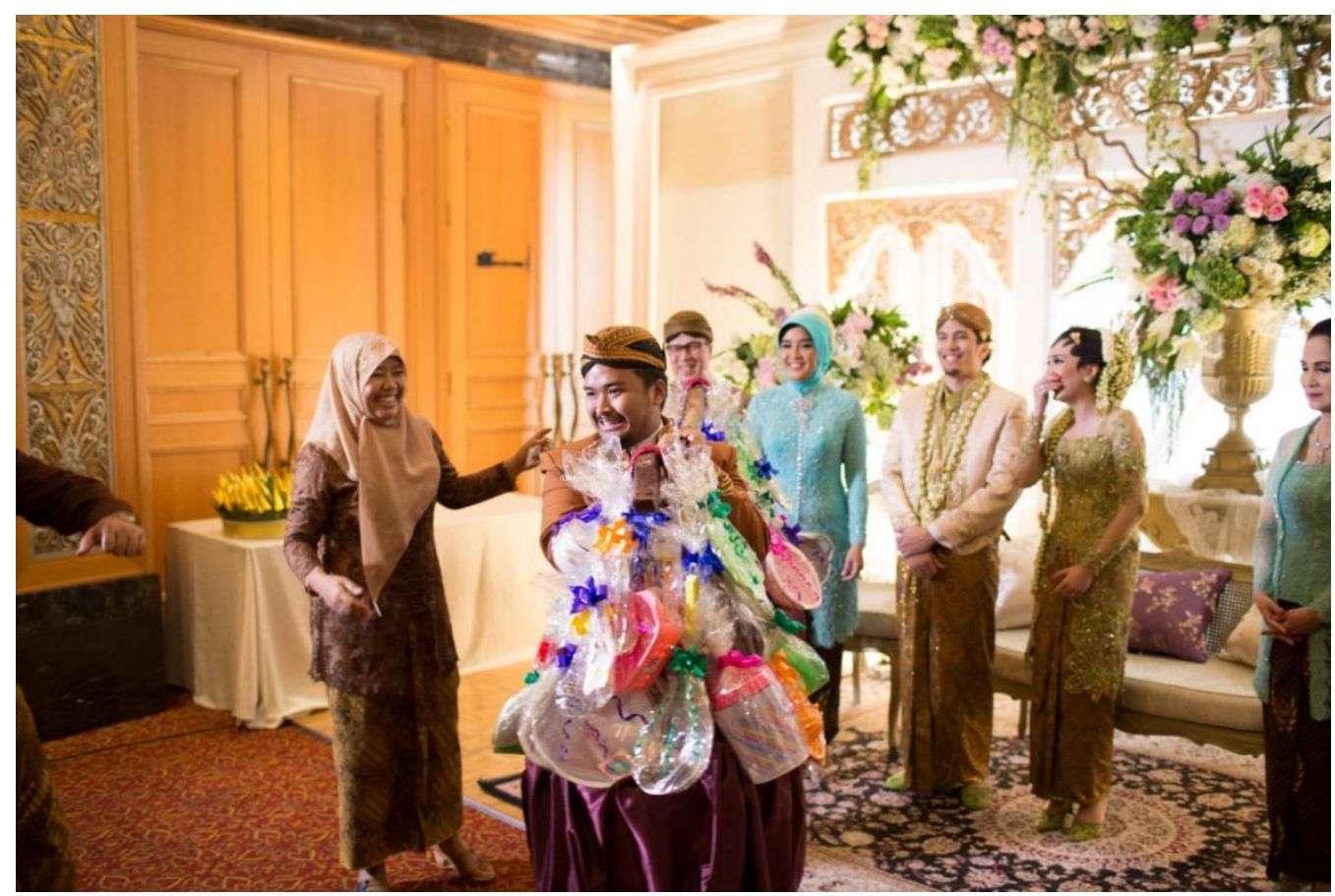

\subsection{Cultural Meaning of Bubak Kawah Ritual}

Cultural meanings are created by using symbols. A symbol is any object or event that refers to something. The symbol itself includes anything we can feel or experience. The symbol referred to in this study is the terms in bubak kawah ceremony. The term in the ritual of bubak kawah includes rujak degan and pikulan.

Rujak illustrates how much parents care for their children, and how hard it is to organize the first manton, as well as opening new land, but for the sake of child survival and continuity of descendants undoubtedly the feeling of being light and fresh, like fresh rujak degan [8]. Pikulan consists of various household appliances that will be contested by guests who will attend the Surakarta traditional wedding ceremony. Pikulan describes the bride and groom's determination to build a family based on the blessing of parents and family and relatives. Invited guests who were present who fought over household appliances at the bubak kawah ritual were expected to be able to share the joy and be willing to give prayers to the bride and groom. In general, the prayer given is about the safety and trustworthiness for the bride and groom [10].

\section{CONCLUSIONS}


It is concluded that bubak kawah ritual in Surakarta traditional wedding ceremony is less noticed and understood nowadays. The emergence of new perspectives on modern wedding ceremony and marriage makes a variety of rituals which are the parts of Surakarta traditional wedding ceremony almost disappear. This study discusses the cultural meaning of bubak kawah ritual at Surakarta traditional marriage. Broadly speaking, the bubak kawah ritual has cultural significance as a means of giving prayers to the bride and groom in order to always be given salvation and happiness both in the world and the hereafter. Prayer for the bride and groom is a prayer offered by invited guests and all relatives who attended the event.

\section{REFERENCES}

[1] Koentjaraningrat, Kebudayaan Jawa. Jakarta: Balai Pustaka, 2001.

[2] B. Busro and H. Qodim, "Perubahan Budaya dalam Ritual Slametan Kelahiran di Cirebon, Indonesia,” J. Stud. Agama dan Masy., vol. 14, no. 2, pp. 127-147, Sep. 2018.

[3] L. J. Maloeng, Metodologi penelitian kualitatif. Bandung: PT Remaja Rosdakarya, 2010.

[4] S. Azwar, Metode Penelitian. Yogyakarta: Pustaka Pelajar, 1999.

[5] H. B. Sutopo, Metodologi Penelitian Kualitatif. Surakarta: Sebelas Maret University Press, 2002.

[6] E. M. Z. Fajri and R. A. Senja, Kamus Lengkap Bahasa Indonesia. Semarang: Difa Publisher, 2008.

[7] N. S. P. Suseno, Pasemon ing Tatacara lan Upacara Penganten Surakarta. Surakarta: Cendrawasih, 1992.

[8] H. Bratasiswara, Bauwarna: Adat Tata Cara Jawa. Jakarta: Yayasan Surya Sumirat, 2000.

[9] M. N. Nafifa, "Persepsi Masyarakat Terhadap Tradisi Bubak Kawah di Desa Kabekelan Kecamatan Prembun Kabupaten Kebumen," ADITYA-Pendidikan Bhs. dan Sastra Jawa, vol. 6, no. 2, pp. 105-111, 2015.

[10] R. S. Yatmana, Tuntunan Kagem Para Pranatacara Tuwin Pamedhar Sabda. Semarang: Aneka Ilmu, 1994. 